\title{
ENTWINED IDENTITIES AND STREET FIGHTING: REVISITING CULTURE AND POLITICS IN NORTHERN IRELAND
}

\author{
Alfred Markey; Universidad de León ${ }^{1}$ \\ Email: ammar@unileon.es
}

\begin{abstract}
Belfast has once again been the scene of protests and sectarian street fighting. Specifically, the violence of late 2012 and early 2013 came in the wake of the decision by the city council to restrict to 16 a year the days on which the union flag would be flown at City Hall. This decision was interpreted by young loyalist protesters as a cultural war on their community. In this article I contrast this interpretation with the model of culture and identity proposed by the President of Ireland, Michael D. Higgins, and with a view to highlighting the value of this cultural model, I also contrast it with the recent history of "conflict" between academics which has taken place in relation to the so-called "Irish question".
\end{abstract}

Keywords: Michael D. Higgins; Irish question; conflict; revisionism; postcolonialism.

Title in Spanish: Identidades enlazadas y lucha callejera: La cultura y política de Irlanda del Norte revisitada

Resumen: Belfast ha sido, una vez más, escenario de protestas y luchas callejeras de índole sectaria. Concretamente, la violencia de finales de 2012 y principios de 2013 se debe a la decisión tomada por el ayuntamiento de la cuidad de hacer ondear la bandera británica solamente 16 días al año. Dicha iniciativa ha sido interpretada por los jóvenes manifestantes "lealistas" como una guerra cultural contra su comunidad. En este artículo se contrasta esta interpretación con el modelo de cultura y de identidad cultural propuesto por el presidente de Irlanda, Michael D. Higgins, y a modo de resaltar el valor de este modelo cultural, también se hace hincapié en su diferencia con la historia reciente de "conflicto" entre académicos que se ha dado lugar en torno a la llamada "cuestión irlandesa".

Palabras clave: Michael D. Higgins; la cuestión irlandesa; conflicto; revisionismo; postcolonialismo.

Clashes on Saturday left 16 police officers injured as they tried to quell the violence. At one point there was hand-to-hand fighting between Catholic residents of east Belfast's Short Strand area and loyalist marchers returning from the city centre. Riot police fired at least four plastic bullets. (McDonald 2013)

Date of reception: 30 June 2013

Date of Acceptance: 5 November 2013 
It is thus that Henry McDonald, Irish correspondent of the Guardian newspaper, reported from Belfast not in the 1970s but in January 2013. The motive was the violence surrounding a series of "illegal" street marches to the city centre which took place over three months on account of the decision taken by Belfast City Council in December 2012 to limit to 16 the number of days on which the union flag would, henceforth, be flown at Belfast City Hall. Attempting to gauge the thinking behind the marches, McDonald reported one 20-year-old's opinion that:

It's also about demonising the Protestant community, portraying us all as thugs. I am joining these protests because there is an attack in a cultural war against our community. We are told, 'You can't parade here', 'You can't play certain songs' and now, 'You have to take the flag down'. We can't sit back and let our Britishness be stripped away any more. (2013)

A very clear perception exists on the behalf of the protesters both that what they understand as their cultural identity is under threat, and that by taking to the streets and by performing their identity, by giving cultural expression to that identity through songs and via the public display of the flag with which they identify, terrain will be gained, so to speak, in what is considered a cultural war.

Little over a month before the beginning of these protests an alternative interpretation and performance of cultural identity took place at Queen's University in the city which offers us an interesting counterpoint to the aggressive codes of cultural expression of the marchers. Presented as part of what he called "a continuous reflection on identity and belonging", the President of Ireland, Michael D. Higgins, in a lecture entitled "Of Migrants and Memory", proposed as his central trope an image of a basket described as "entwined" and in effect performed in "migration" (2012). Ending with a poem from Nuala Ni Dhomhnaill which gives "an account of a journey begun in hope and apprehension that concluded with undreamed of rewards", that of the destiny of "Moses in an entwined basket", President Higgins proposes that:

No matter how rooted and sedentary our lives, we are all migrants -if not in space, then certainly in time. Those migratory patterns, adjustments and revisions are particularly evident in the human interconnectedness of these islands and we are all the richer for them, facing a shared future beyond the binds of any abused reason or the hubris of false certainties but rather empowered by the impulse of the heart- we go where our intertwined basket takes us, towards an enduring peace and a shared future. (2012)

The reaction of the marchers might seem to suggest the President was being perhaps overly sanguine, or that his vocabulary of "enduring peace" was just another glib pronouncement more attuned to political expediency than to the realities of on-going sectarian tension. This would, however, be to do the President a considerable disservice. In a manner consistent with the values espoused throughout his political and academic career, Higgins employs a language which intends to engage a wide public, and to promote a traffic of ideas between intellectuals such as himself and those less accustomed to participation in 
the public space. ${ }^{2}$ Also, the carefully chosen metaphors and themes utilized in the specific content of his address speak to the broader question of the significance of the context within which discourse may be understood, in this case the institution where he gives his speech, or, performs the very ideas he has chosen to promote. The occasion is, in fact, the 2012 British Council Annual Lecture and it is within the framework of this institution for the promotion of specifically British culture that he chooses to articulate a heritage which is shared between Britain and Ireland, and is protagonised by a diversity of "human connections", as he puts it (Higgins 2012).

Notably, he also begins his address by acknowledging that his intervention is intended as a dialogue with what is in part the source of the metaphorical compass employed: the series of four volumes of essays entitled Lives Entwined published by the British Council itself. His act of cultural expression thus takes place both inside and outside the "British" tradition. Higgins's dialogue with the notion of entwined lives involves both a celebration of its potential as an enabling concept, as a template for dialogue, but also as a recognition of how it offers testimony to the still troubling realities of the involved cultural imbroglio that is the British-Irish interface:

The word entwined may seem particularly apt at first glance. It contains the notion of strength and also of multiplicity of strands, not one source of connection but many, grown as much by custom and accident as by design. But, 'entwined', as a concept, contains too a sense of entanglement of knots tightly made and difficult to undo and I wish, in this lecture, to consider the function of addressing memory and the confrontation of stereotypes in this task. The undoing of the difficult knots of memory, I suggest, requires a willingness to acknowledge old assumptions and destructive stereotypes if we are to share together such a pilgrimage in the ethics of memory as will serve a still maturing peace in the present - if it is to become, as we all hope, an enduring peace for our shared future. (2012)

Here in this article I wish to, in turn, dialogue with the template of intercultural engagement proposed by President Higgins in order to revisit the history of debates around culture and academia which have marked the Northern conflict, while doing so with a view to allowing memory and history, in a sense, speak to the recent tensions with which we began. Significantly, in McDonald's Guardian piece he draws a contrast between those who express opinions along the lines of the 20-year-old quoted above and older loyalists. Veteran loyalist activist Raymond Lavery, for example, commented the following to McDonald: "I remember gun battles in my street in 1970 when we had to hide under the stairs to be safe. These young people out here today didn't live through any of that; they can't imagine what it was really like" (McDonald 2013). Significantly, Lavery indicates that a key problem was that of the ability of the young generation to properly interpret the full significance of initiatives such as the lowering of the flag. In other words, as he puts it, what was "desperately needed was a political education programme to convince younger loyalists that their fears may not be realised" (McDonald 2013). Lavery clearly perceives the lack of ability on the behalf of young loyalists to contextualise and so afford nuanced interpretation and meaning to specific contemporary actions.

See Higgins's collections of essays Causes for Concern (2007) and Renewing the Republic (2011). 
Higgins similarly draws a distinction between generations and proposes his reflection on identity and memory as undertaken in dialogue with the third volume of Lives Entwined essays, specifically on identity and memory, which had been written by a mature generation of commentators, but also with Volume Four. He explains: "Volume Four with its frank and impressively honest expressions by young people on their experiences of identity, encounters and more than that, the full flowering of a peace yet to be encountered at community level" (Higgins 2012). Higgins, in a sense puts his finger on the pulse of discontent among the young people and almost anticipates the conflict that would come to pass in the months after his intervention. He states: "It is interesting too to contrast the undeniable optimism of the reflections in Volume Three with the uncertainty that is at the heart of Volume Four to which the young people have contributed" (2012). In essence, what he proposes from the out is the cultivation of comparative perspectives. He proposes as germane to Northern Ireland's needs at this time the sort of broad education that Lavery similarly called for, and which can be given metaphorical expression in the idea of migration and the conceptualising of spatial and, crucially, temporal displacement as potentially productive of an empowering capacity for critical apprehension of shared territories, intertwined historical narratives and the interpretation of the enabling power of culture, particularly of literary, troped language to engender a dynamic of peace rather than conflict.

Significantly, Higgins talks of the need for a reworking of memory and for addressing and revising stereotypes and renovating our narratives with an emancipatory aim. $\mathrm{He}$ recognises that this process involves both the acknowledgement of, and the listening to, the narratives of the other - the recognition of the alterity of the other- but also the courage to identify the historical realities of power relationships which involved hierarchies, most notably that of the coloniser and the colonised. Higgins, in fact, refers to perhaps the key critical influence in postcolonial critique, Edward Said, and does so to echo Said's idea that "everything that is really interesting happens in the interstices" (2012). Higgins continues:

And it is perhaps in the area of migrant lives that this is perhaps most clearly demonstrated. Our social sciences have, I suggest, not only been over-determined in their models but they have also been too sedentary in their assumptions and their methodologies aimed at understanding human migration. They have missed what literature has often caught, the human negotiation of the spaces between the place of origin and the final destination. (2012)

That Higgins should invoke Said, and do so as part of an explicit defence of the worth of literature due to its potential to offer evidence of and templates for negotiation is significant both for the fact that by doing so he positions himself in the same postcolonial tradition as Said, while doing so in a manner which purposefully engages this tradition in order to attach priority to the value of negotiation which involves the other "side".

Said was, crucially, a key player and influence in what can be called the postcolonial strain of cultural politics in Ireland, especially Northern Ireland, since the early 1980s, and so we can consider his involvement and influence as consistent with or expressive of the migratory trope which he himself made great use of, and which is in turn defended by Higgins. To fully understand, however, the resonance of the invocation of Said, it is appropriate to resister that this participation, which we can consider as one of the 
Palestinian's many "migrant lives", formed a constituting element or strand of a cultural project which placed literature at its heart, namely that of the Field Day movement which sought to engage with the conflict in Northern Ireland particularly by recourse to the idea of literature as providing a realm within which more enabling realities and narratives for Ireland and Britain could be imagined. Notwithstanding the noble designs on peace or the negotiation of scenarios more propitious to the imagining of new communities, the Field Day, and broadly postcolonial, project found itself pitched in conflict with an alternative so-called revisionist tradition whose raison d'être was precisely the removal of the mythical, narrative and broadly literary component of history writing with a view to the proposal of a supposedly ideologically neutral and objective rendering of the "facts".

In the light of the current difficulties on the streets of Belfast, it is, one feels, salutary to re-examine or revise the cultural debate which paralleled the conflict in Northern Ireland primarily in order to achieve an educational, historical perspective on current events in line with that called for by the veteran loyalist Lavery. Such a "migratory" perspective is intended, like Higgins's intervention, to offer a critical contrast to the aggressive modes of cultural expression of today's loyalist youths, while it is adopted precisely with the intention of dialoguing or negotiating with their "position" by both invoking and in part critiquing the heritage of cultural engagement in relation to Northern Ireland -specifically its aggressive quality- yet paradoxically doing so in conscious defence of a postcolonial tradition which would initially appear to be that of the other "side". That such a role should be played by Higgins, who has throughout his life defended issues of human rights articulated in solidarity with peoples far from his own ethnic collective, should come as no surprise. And we can propose that this postcolonial idiom in fact speaks eloquently to the needs of a "subaltern" loyalist working class, and to their growing understanding of, in Higgins's formulation "The Transforming Power of Culture" (2012). Indeed, as postcolonial discourse has shown us, political expression is at heart a struggle for a cultural voice.

It is fitting that the last word, the afterword, to the most significant collection of essays addressing the thorny question of the colonial and postcolonial credentials of Ireland, Ireland and Postcolonial Theory, published in the year 2003, should be left to the critic Edward Said. Among the final published words of the now deceased father of colonial and postcolonial discourse analysis, these closing reflections afford us a useful point of departure from which to consider the arrival of postcolonialism to Ireland.

What is at stake, for Said, is no less than "the whole question of Irish identity, the present course of Irish culture and politics, and above all, the interpretation of Ireland, its people, and the course of its history" (2003: 177). Said is here proposing a very broad remit for postcolonial critique in relation to Ireland and he does so in a manner which, far from proposing a prescriptive model of criticism or a defining classificatory rubric under which one can or cannot fit Ireland, is positing the practice of engagement with the large issues around the whole question of Ireland from a postcolonial optic, or via a critical and intellectual language, that has as its guiding paradigm questioning and interpretation rather than answers and defining conclusions.

Homi Bhabha has written that the supplementary has the power to antagonise (1994: 155). However, when we consider the supplementary quality of the afterword of Said, and his support for a postcolonial hermeneutic in the Irish context, we can propose that the intention 
is not exactly to antagonise given that antagonism has been a negative characteristic of issues surrounding Irish identity at all levels of engagement and through most of history. It is, perhaps, again "The Irish Question" we are dealing with but proposing in a manner that does not, like the historical use of the phrase, demand an urgent solution and an ultimate silencing of the niggling dissent against and distraction away from the primary issues of concern, those of the metropolitan centre. ${ }^{3}$

By contrast with such metropolitan impatience, in relation to the broad framework of identity, culture and politics Said recognises as implicated in the consideration of Ireland and the postcolonial question, he proposes a critical approach marked by an always ongoing process of engagement, questioning and supplementary debate in which antagonism is to the closure implicit in clearly established narratives of identity rather than to the participants in the debate itself. In short, a position like that of Higgins in which points of connection between sides are teased out but in a manner which does not ignore historical power relations.

This critical attitude is taken particularly in the light of the events in Ireland over the last forty years. A very tentative peace has been achieved only quite recently between a complex range of disputants and interests, yet, as our opening reference to on-going tensions testifies, we remain a long way from a satisfactory resolution to the conflict, particularly in Northern Ireland. The violence that has been the principle protagonist over these last decades has been the result of the interpretation of ideas of communal and national identity that have proved of sufficient intensity to allow individuals to kill and willingly die for causes that in their most extreme manifestations have not allowed for any questioning dissent, or any conception of a shared terrain or a history of lives entwined. The killing and dying has occurred in part because historical narratives of exclusivity were wrought and continuously articulated in a manner which legitimised violence and conceived identity in oppositional terms where the other side was clearly identified and consequently challenged. If this characteristic division can be seen most graphically in the sectarian separation of the city of Belfast into ghettoes, it has been pervasive in all areas of life and is specifically mirrored in the area of culture, with the writing of and about history and literature similarly marked by tensions where identities have been proposed antagonistically.

We can, thus, along with Higgins, propose that if history writing and interpretation both in its more academic, literary and popular manifestations have contributed to the polarisation that precipitates violence, then perhaps equally history writing, and the production of culture in all its forms may potentially work to contest the ethnic boundaries and may dissent against and work to deconstruct facile conceptions of community identity and historical rights and wrongs. Our intellectuals, our historians, writers and critics can surely offer us different models, different stories that don't aggregate and simplify the complex historical heritage. They, our intellectuals, can perhaps both by interrogating the past, and by providing challenging new narratives, tropes and paradigms of intellectual engagement, serve to contribute alternative visions ultimately more enabling than the end-game of confrontation that has historically been so characteristic of Anglo-Irish relations. One of Ireland's most notable contemporary historians, Roy Foster, has, in fact, confidently suggested that the

\footnotetext{
"The Irish Question" was the euphemism used in the UK throughout the nineteenth century to refer to the Irish movement for Home Rule. Its employment habitually suggested impatience with a debate that seemed to continuously reinvent itself in defiance of metropolitan rulings and attempts to achieve final closure.
} 
current peace process is, even if to a small degree, due to "subversive history-writing" (1995: 21). ${ }^{4}$ Perhaps so, yet, unfortunately, the confrontational dynamic mentioned seem to an overwhelming extent to have been the key characteristic of the debates that have taken place over recent decades with regard to the establishment of appropriate frameworks and theoretical suppositions on which to engage with the vexed question of Irish identity and its expression in historical and literary texts.

In his ground-breaking Orientalism, following the lead of Michel Foucault and Antonio Gramsci, Said investigated in depth the degree to which knowledge, meaning and identity have historically been produced and created by the institutions of hegemonic powers, with the consequence that the knowledge produced is valorised and inflected by the institutions from which it emerges and in which it is interpreted (1995). Aside from the fundamentally important idea of the narrative form as a key determinant of meaning, we may also consider such categories as History, Literature and the Nation State as basic determinants of the type of knowledge and identity produced: their importance of course determined by the institutions which give them shape and indeed by the wider political and historical circumstances that we can provisionally call colonial or to a degree postcolonial.

This is clearly borne out in contemporary engagements with what Said identified as "the whole question of Irish identity, the present course of Irish culture and politics, and above all, the interpretation of Ireland, its people, and the course of its history" (2003: 177). When we consider how intellectuals have engaged with the above, we find a broad division between, on one hand, those who approach these issues from the perspective of History, particularly the so-called revisionists, and those who engage from the viewpoint of Irish studies.

The field of academic and intellectual enquiry generally termed Irish studies emerges particularly from the discipline of English. It is, in other words, the realm of practitioners of literary criticism, that discipline perhaps first given significant institutional shape by Matthew Arnold in England in the nineteenth century. His initiative was instrumental in the establishment of departments of English literary criticism in English universities, along with the gradual privileging of a set or canon of appropriate texts selected on criteria of literary merit which assumed a relatively unproblematic objectivity. In due course similar departments were established in the Irish universities and subsequently the subset of Anglo-Irish literature was developed, later evolving into the more ample framework of Irish studies which we have today. We see in such an evolution unequivocal evidence of precisely the sort of entwined strands and points of connection Higgins chose to highlight in his proposal of a continuous reflection on identity and belonging.

So, this intellectual context of Irish studies has not, evidently, been impermeable to the influence of other related fields particularly that of English studies. Equally, although less so initially, English studies was to be influenced in turn by the sub-disciplines that emerged as

\footnotetext{
Foster here refers to interpretation even though revisionism generally shies away from interpretation as a guiding intellectual influence, preferring instead a discourse of factual empiricism. For a particularly balanced consideration of the debates around cultural politics and postcolonialism, in which interpretative dialogue expressed as the search for a "flexible foundation" and manifest as a desire to continuously re-question rather than reaffirm or claim intellectual dominion, can be found in Dawn Duncan's “A Flexible Foundation: Constructing a Postcolonial Dialogue" (2002).
} 
it sought to encompass the totality of periods, locations and tendencies of writing in English in what was a characteristically colonial move to chart and document all areas potentially within its remit. Particularly important was the growth of the study of the literature in English from the so-called "Commonwealth" countries. These were, of course, the former colonies of the British Empire which latterly formed the voluntary body of associated sovereign countries termed the "Commonwealth of Nations". The development of this field of study from the 1950s coincided with the progressive independence of the former colonies and was from the beginning seen as indicative of the new relationship which considered the former colonies on a par with the "mother country", and not in a position of subservience as had previously been the case. This was, nonetheless, wishful thinking. At the first conference on Commonwealth literature held in 1964 in England, A. Norman Jeffares expressed the view that "one reads [Commonwealth writers] because they bring new ideas, new interpretations of life to us" (qtd. in McLeod 2000: 12). The dynamic of the culture of the colonies being put to the service of the metropolitan centre is in evidence.

Yet, as a result of the opening up of the field to a diversity of ideas, particularly following the subsequent engagement with the colonial discourse theories of Franz Fanon and Said and the later influence of poststructuralist thought and literary theory, most notably through the work of Bhabha and Gayatri Spivak, Commonwealth literature became decentred, and mostly evolved into the more radical practice of postcolonial studies. We thus begin to see the developing phenomenon of the empire writing back, critically reflected in the seminal, eponymous attempt at a classification of this emerging literature by the Australian critics Ashcroft, Griffiths and Tiffin. However, their The Empire Writes Back, in contrast to the tendency of English literary studies to attempt to incorporate for example "the best" of Irish literature into its own canon, is keen to keep Ireland out, disallowing the entry of its literature into this new canon because although it was possible to consider the likes of Ireland, Scotland and Wales as "the first victims of English expansion, their subsequent complicity in the British imperial enterprise makes it difficult for colonized peoples outside Britain to accept their identity as post-colonial" (1989: 33). Ashcroft et al.'s classification is far from unproblematic and it appears that an exercise in selection and valorisation akin to that of the Arnoldian canon-making is being undertaken. Such a classificatory approach in which certain peoples, places and literatures are either in or out of the "club" appears to replicate the colonial model and is markedly different to the interpretative, critical model of engagement with ideas and people proposed by Said and evidenced in a certain mould of recent comparative literature which aims to dialogue across borders rather than establish their lines of division and definition. Again we can establish a continuity in Higgins's valorisation of the potential of literature to, so to speak, negotiate across categories, whether human or merely cultural, and to encourage a sensibility to the entwined geneology of people and knowledge, as against a social science methodology of classification far too "sedentary" in its assumptions and methodologies (2012).

It is not our task here to outline in depth the historical developments in the area of postcolonial studies but it is of interest to note that the aforementioned Jeffares, a pioneer in Commonwealth literature, subsequently became a key founding member and organiser of the inaugural conference of the International Association for the Study of Irish Literature (IASIL) in 1970. It is thus unsurprising, and reflective of the translatability, or "migrancy" 
in Higgins's vocabulary, of ideas, that the contemporary use of the colonial/postcolonial framework within which to consider the development of Ireland should be employed initially and most consistently by intellectuals working within the field of English language literary criticism. If in the past this discipline was seen as the preserve of the aesthetic, that magically transcendental realm somehow capable of breaking free from political and social circumstances, over recent decades it has engaged vigorously with contemporary "theory". In addition, as we can see in the above example of Jeffares, the tendency has been to increasingly open the field up to external and international influences with the ferment of ideas emerging from developments in Commonwealth countries, for example, progressively impacting on the nature of literary studies in Ireland.

In the case of Commonwealth literature the very constitution of the field was in great measure a consequence of political developments: in the mid-century struggle for the independence of emerging nation states the dynamic of decolonisation was, in these countries, the overwhelming determinant in all spheres of human endeavour. And given the great potential of culture as a productive practice where identity could be forged, it was natural that its importance should be foregrounded and that a parallel highlighting of the relevance of politics to culture and of culture to politics should occur. In the Irish case, the evidently important historical role of culture and its radical politicisation, particularly in the Literary Revival, would seem to irrevocably link culture and politics, yet it has only been in recent times that literary academics have begun to make sustained efforts to engage with the political and the historical not as just thematic adjuncts to cultural items whose main interest is their aesthetic worth, but as categories without which a full understanding of the literature is impossible.

This development seems, however, not be to everybody's liking. If from the colonial world we find some resistance to the consideration of Ireland on its terms, to the colonisation of their patch so to speak, at home similar tensions are much in evidence. For example, even historian Nicholas Canny, himself an advocate of the application of the Atlantic and colonial frameworks in Irish historical analysis, has complained of the influence of "people who are involved in post-colonial theory", "lecturers in literature, the social sciences, etc. are colonising history as their own and these are people who seem [...] to have simplistic answers supported by a limited amount of historical evidence" (qtd. in Howe 2000: 108). The rub, nonetheless, is the contemporary political consequences of such thinking: "What offends me is that people who might read a piece of mine on Edmund Spenser suddenly zoom from that to talk about the recent IRA campaign and would say that this was fully justified because of what Spenser said" (qtd. in Howe 2000: 108).

Yet it is disingenuous in the extreme to imply that this is, in fact, characteristic of the majority of the work by scholars engaged in "postcolonial" analysis in the Irish context. Whilst Canny may encounter the occasional student, or even academic, who interprets history in such a limited way, the evidence of the work produced by the key protagonists in the field suggests that, far from jumping to easy conclusions, the tendency is rather to shy away from wild affirmations and to question and re-question accepted shibboleths, concepts and frameworks, again to deal in questions rather than answers. The emphasis tends to be on tracing contingency more than on confirming hoary truths. Indeed, even David Lloyd, one of the recognised doyens of the Irish postcolonialists, ends his influential Anomalous 
States referring, in apparent contradiction to all that had gone before, to "Ireland's putatively "post-colonial" culture" (1993: 155). Therefore, when we find Canny's perhaps occasionally legitimate concerns reproduced in preface to a consideration of the contributions of the more prominent exponents of postcolonial studies, the juxtaposition itself hints at an attempt to misrepresent the nature of the research that been produced and to offer, in Canny's words, "simplistic answers" to complex questions.

This, however, is to a degree what we find in Stephen Howe's Ireland and Empire: Colonial Legacies in Irish History and Culture, a book whose preface to the paperback edition quotes Richard Kirkland's remark that "few books in recent years have created as much controversy within Irish Studies" (2000: viii). Certainly, in the light of such unfortunate attempts to misrepresent the reality of Irish postcolonial studies as that of Canny, this is unsurprising. But it is equally revealing that Foster, the single most important contemporary exponent of the revisionist tendency, should laud Howe's study as "magisterial" while elsewhere lamenting the "simplistic application of Frantz Fanon's One Big Idea to an Irish situation sweepingly redefined as 'post-colonial"' (1995: 28-29). To find Fanon's dramatically engaging and seminal work summarily dismissed in these terms indicates a reluctance to deal with the issues raised by the postcolonial critics and a determination to collect quite a heterogeneous range of scholars under a reductive label. One is tempted to seek clarification as to exactly which of Fanon's ideas is deserving of such a vaunted status. In any case, this is ultimately unsurprising and to a great extent consistent with colonial discourse where native colonised culture is misrepresented in wildly simplified terms for the consumption of the "mother" country. In this case Howe and Foster, alternatively scholars in politics and history at Oxford University, don't seem to tell the whole story. Howe accuses the literary critics of a "cultural reductionism" (2000: 109), while simultaneously lamenting their incursion into the sphere of history and politics. ${ }^{5}$

Can we perhaps identify in Howe's dismissive stance a hostility towards any scholarship seen to be engaging in a "colonisation of History" that is reminiscent of Canny's position? The question arises whether this turn responds just to a dissatisfaction with the content of the scholarship itself, or because it crosses outside the frontiers of a conservatively understood notion of areas of academic expertise. In this very rejection of the interdisciplinary or comparative turn we can interpret a de facto defence of strict compartmentalisation of academic disciplines and fields which is an effective correlative of the defence of the existing political realities. As we have already noted, the model of the establishment of relatively fixed sets of canons and authors ("the best that we have known" in Arnold's vocabulary) and the practice of scholarly expertise about these without the need to go beyond the canon itself, is in fact a legacy of the model of cultural nationalism established by and in the interests of British and particularly English rule.

Similarly, the relationship of such academic activity to the empowered institutions of the state is one where individual academics become officially licensed to engage in a particular speciality with conservative social manners dictating that to go outside the place of one's own area is to, in effect, invade that of another fellow professional. It is, so to speak, not the

\footnotetext{
5 At the time of publication of Ireland and Empire Howe was a Tutor in Politics at Ruskin College, Oxford. Subsequently he became Professor in the History and Cultures of Colonialism at the Department of Historical Studies, University of Bristol (UK). Foster holds the Carroll chair in Irish History at the University of Oxford.
} 
done thing, with conservative discretion the preferred model. Such academic specialisation is rigorously critiqued by Said, for example in his Reith lectures on the public intellectual (1994), and his model of academic is in fact strikingly apposite when considering the public interventions of both Higgins and the loyalist marchers with whom we began. The intellectual model of Howe and the revisionists, however, involves the strict separation of disciplines but also crucially seeks to remove the intellectual, the writer and the critic from engagement with politics and the public sphere, or the street, even while they themselves are often reserved the privilege of entering the political ring, if only in order to tell the others to get back to their literary thing, so to speak. Its values are those of a liberal humanism which in its various guises insists on the strict separation of politics and culture and underwrites the authority of the functioning state in which everybody, in Louis Althusser's words will "work by themselves" in a discreet, depersonalised mode (qtd. in Lloyd 1999: 34). Such a reality of course presumes a sense of a properly functioning state, clearly a problematic categorisation in the case of the Northern Ireland of the troubles.

So, when revisionist historians, even in the face of the violent meltdown of recent decades, call on the literary academics to stay within their specialist area we can understand it as redolent of what Marxist critics would term a disciplining interpellation where they are called on to mutely take up their "natural" position in the order of things. By contrast, Said's emphasis is on questioning and interpretation as part of his sort of postcolonial critique which aims to be determinedly inter-disciplinary in approach and which is influenced by the rigorous debate which emerges from the engagement with the multiplicity of perspectives that inform colonial and postcolonial discourse.

In Howe's book, unfortunately, the lines of engagement seem to be clearly drawn and the initial antagonism is seldom dissipated even where the evidence would seem to point towards a correction of the initial suppositions. The author, for example, takes literary scholars to task for failing to consider, as he explains, "the extent to which colonial rule in general, and the British Empire in particular, was a patchwork quilt, an enormously varied set of forms of rule and domination, largely the product of improvisation and full of internal contradictions and strains, rather than a deliberately constructed global system" (Howe 2000: 110). He does initially seem oblivious to the fact that much of what he says, such as the above comments about British colonial rule's internal contradictions and strains, would not be out of place in the work of one of those ostensibly on the "other side" of the dichotomy he appears to cultivate. Later, Howe demonstrates a considerable familiarity with the work of the literary and cultural critics who are influenced by colonial discourse analysis when addressing them specifically, yet here the tone is notably less combative with concessions being made to the reality that the various components do not in fact form a monolith (2000: 111). Nonetheless, although it seems as if the specific investigation of the work that can be broadly defined as "postcolonial" discredits the initial thesis that it offers simplistic answers and reductive generalisations, this does not seem sufficient to warrant a subsequent correction of the initial supposition.

We do seem here to be falling into what Said, in "Intellectuals and the Post-Colonial World" called the "blame game" which perpetuates the Manichaeism he identified at the heart of Orientalism and of which hostile critics have unfairly accused Said himself (1986: 45). And it is unsurprising, given the tenor of Howe's arguments, that Said should describe 
him, somewhat simplistically it has to be said, as an "English supporter" (2003: 179). Indeed, the debate around culture, politics and identity in Ireland sometimes appears antagonistically tribal, even reminiscent of the sectarian clashes that characterise the marching season in Northern Ireland and which has, of late, found expression in the loyalist protests of late 2012 and early 2013. W. J. McCormack, in his appropriately entitled The Battle of the Books, pointed to the arrival of the Field Day group as the initiative that brought about the unprecedented tension to the field of engagement. Its members were a "tightly structured team of polemicists" responsible for "alliances and antagonisms new to Irish literary debate", with the group's enemies reviewing "a Field Day pamphlet as if it were some edict imposed on defenceless readers by an unstable and treacherous Fate" (qtd. in Howe 2000: 110).

Shaun Richards has used the term "street fighting" and, unfortunately, at times it appears wholly appropriate as scholars fight to defend their "field" or patch (1999: xii). The almost sectarian quality of the debate is heightened when religion itself becomes the issue under discussion. The seventy-fifth anniversary of the Easter Rising saw the publication of a series of essays, Revising the Rising, in which the primary intellectual influence behind the Field Day project, Seamus Deane, in his contribution "Wherever Green is Read", undertakes a strident deconstruction of a passage from perhaps the flagship revisionist text: Foster's Modern Ireland 1600-1972. Deane quotes Foster's view that: "an intrinsic component of the insurrection (for all the pluralist window-dressing of the Proclamation issued by Pearse) was the strain of mystic Catholicism identifying the Irish soul as Catholic and Gaelic. It could be argued that this was nothing new: literary Fenianism yet again" (1994: 234). ${ }^{6}$ For Deane "the whole point of Foster's representation is that the Easter Rising was an exercise in irrationalism, a word entirely congruent with nationalism (of the Irish, not the British, kind) and that it was read as such in Ulster. The legacy of the Rising is the Northern crisis" (1994: 236).

This Northern crisis, the clash between Catholic nationalism and Protestant unionism is thus clearly not at a remove from ivory tower academics busying themselves over dusty manuscripts and obscure themes with little relevance in the present day. The interpretation of the past has been of paramount importance to the understanding of a conflict ongoing in the streets as the historians and cultural critics write. Deane continues:

For the reaction to Easter 1916 is part of the reaction to the Provisional IRA. The lamentations about that organisation's use of violence in the furtherance of political ends come most loudly from those who have a well -established notoriety for that practice themselves- the British and the unionists. They are not opposed to violence as such; they are opposed to violence directed against them. But they are perfectly happy to direct violence against their opponents and even, if need be, against one another. (1994: 237)

Clearly Deane sees revisionist historiography as responding to the events at the time of writing. It is guilty of revising the rising through the interpretative prism of the "troubles" while presenting this as much more objective scholarship than that engaged in by the other side. In effect, he perceives Foster articulating a view of the events at the beginning of

$\overline{6}$ Reprinted in Brady (ed.) Interpreting Irish History: The debate on Historical Revisionism 1938-1994. 
the century determined by the political relations at the end of it. For Deane it is a violent violation of history, unionist style.

In the work of Foster we find a similar distrust of history with a present-minded slant. But in this case the main culprits are those of the nationalist tradition. In his engaging study of the tradition of writing the Story of Ireland the eponymous essay has him rueing the prevalence of a "mercilessly present-minded preoccupation", even, when referring to A. M. Sullivan's late nineteenth century text of the same title, the tendency to imagine "Home Rule three thousand years avant la lettre" (1995: 9). Foster's tone is generally less combative than that evidenced in Deane's "Wherever Green is Read" -probably Deane's most radical contribution to the debate- but he can equally test the borders of "acceptability". As Terry Eagleton notes, reviewers of the 2001 volume of essays, The Irish Story, variously described it as "scathing", "combative", "withering", "cutting" and of course, "polemical", with Eagleton himself, in a Guardian newspaper review, quick to laud Foster's subtle intelligence while cuttingly remarking: "Though The Irish Story is needlingly partisan, its author tends to believe that partisanship, like halitosis, is what the other fellow has" (2001).

He continues, clarifying:

The book uncritically celebrates posh Irish Protestants, while reserving most of its flak for nationalist Gaels. It is withering, on the whole, about Irish anti-colonialism, but much more reticent about rebuking the unionists. The only form of colonial exploitation it will admit to is non-Irish writers muscling in on Irish studies -and this from a cosmopolitan spirit supposed to abhor parochialism. Those on the outer darkness who muscle in on Foster's own political side, oddly enough, are rather more welcome to the club. (Eagleton 2001)

Indeed, this unfortunately seems to be what we are dealing with: the "club", the political side, the debate engaged in from irremediably polarised and partisan positions. More than the content of the debates undertaken, the chief characteristic of discussions on politics and culture in Ireland does seem to be the polarisation between sides. The newcomer to the field must surely be struck immediately by the extent to which the protagonists, scholars with immense international reputations such as Deane and Foster, not to mention Eagleton, appear to engage with each other on the cultural plane in a manner reminiscent of the street confrontations that mar every Northern Irish summer when territory is loudly and ceremoniously marked into spaces of exclusivist belonging.

We are, it seems, dealing with what are generally referred to as the "two traditions". Edna Longley, in her important contribution to the debate on literature and revisionism, The Living Stream, quotes from Stopford A. Brooke's introduction to his 1900 collection of poetry, A Treasury of Irish Poetry in the English Tongue, part of a controversy reprinted in the Field Day Anthology of Irish Writing and mirrored in the debates over the last decades:

This new movement took two lines, which ran parallel to one another, like two lines of railway. But now and again, as lines of railway meet and intersect at stations, these two mingled their motives, their subjects, and their manner. But on the whole, they ran without touching; and one followed the English and the other the Irish tradition" (1994: 17). 
Brooke went on to conclude that of these turn-of-the-century poets "there was one element common to them all. It is their nationalism" (1994: 17). To a considerable degree that seems to remain the case with these newer traditions except that the exclusive nationalisms, at least until recent times, have been characterised as much as anything by antagonism, by coming into aggressive contact at the sectarian interface. And, as we can see, those who contribute to the debate from outside seem similarly to be drawn unconditionally to one side or another -witness the examples of Eagleton and, on the evidence give above, even Said.

It can, of course, be feasibly argued that this seemingly irremediable Manichaeism is the product of the British colonial presence, a presence that still echoes in the Southern Republic and is overt in the North. Even though, as the controversy over the flying of the flag at Belfast City Hall demonstrates, its dominion is now a negotiated one, and its symbols are not omnipresent but instead are given public presence, or performed, even articulated in a manner which takes into account the perspective of the other "side". Similarly, academic enquiry can be seen to increasingly attempt to accommodate the other, as evident, for example in measured studies such as Eoin Flannery's 2009 Ireland and Postcolonial Studies which examines the history of culture and politics in Ireland through a postcolonial critical idiom, but which very fairly engages with the perspectives of the revisionists; or work such as F. C. McGrath's "Settler Nationalism: Ulster Unionism and Postcolonial Theory", which examines Ulster unionism and loyalism by means of a sympathetic employment of postcolonial discourse.

But again, it is perhaps Higgins who offers us the most significant example. In particular his role as, in a sense, both political and intellectual head of the Southern state, affords his interventions a special power to mark the shape of debates. To a considerable extent he follows the bridge-building template so well promoted by his predecessor, Mary McAleese, but it is his multi-faceted trajectory as an academic, a writer of literature, a campaigner for universal rights, and his political life dedicated to the cause of the subaltern which leaves him in a privileged position to engage with working-class Protestantism as someone who gives personal expression to the idea of a life entwined, and so credibly perform the migratory model of renegotiated identity and belonging he espouses.

As we approach the commemoration of 1916 and the prospect of a renewal of hostilities over both flags in the street and academic tussles over Ireland's heritage of identitarian narratives and our liberationist traditions, it is fair to say that the potential benefits of having as head of the Southern state a scholar particularly sensitive to both the dangers and the potential of cultural expression are considerable. Our difficult "knots of memory", can only be undone, Higgins suggests, by recognising old assumptions and destructive stereotypes, and, it is from this sort of an educational engagement with the past that the potential develops "to share together such a pilgrimage in the ethics of memory as will serve a still maturing peace in the present" (2012). Although his roots can be identified as in part postcolonial, his "literary" migrations also allow him to partake of the language of revisionism in his proposal of an imaginative template of what is, at bottom, a secular or non-sectarian pilgrimage which can articulate a vocabulary of "warm reciprocal relationships" by means of a "reworking" or "revision" of history, and "a mutual self-interrogation in history" which is, one feels, infinitely more promising than marches of any colour or fighting in defence of any flag (2012). 


\section{REFERENCES}

Ashcroft, B., Griffiths, G. and H. Tiffin. 1989. The Empire Writes Back: Theory and Practice in Post-Colonial Literatures. London: Routledge.

BнавHA, H.K. 1994. The Location of Culture. London: Routledge.

Deane, S. 1994. "Wherever Green is Read". Interpreting Irish History: The Debate on Historical Revisionism 1938-1994. Ed. C. BRADY. Dublin: Irish Academic Press. 234-245.

Duncan, D. 2002. "A Flexible Foundation: Constructing a Postcolonial Dialogue”. Relocating Postcolonialism. Eds. D. T. Goldberg and A. QuaYson. Oxford: Blackwell. 320-333.

Eagleton, T. 2001. "Welcome to Blarneyworld". Rev. of The Irish Story: Telling Tales and Making it up in Ireland, by R. F. Foster. The Guardian 27 Oct. 2001. 20 June 2013. http://www.guardian.co.uk/books/2001/oct/27/historybooks. highereducation?INTCMP $=\mathrm{SRCH}$

Foster, R.F. 1995. The Story of Ireland: An Inaugural Lecture delivered before the University of Oxford on 1 December 1994. Inaugural Lectures. Oxford: Oxford University Press.

Flannery, E. 2009. Ireland and Postcolonial Studies: Theory, Discourse, Utopia. Hampshire: Palgrave, Macmillan.

Higgins, M. D. 2012. [2007]. Causes for Concern: Irish Politics, Culture and Society. Dublin: Liberties Press.

---. 2011. Renewing the Republic. Dublin: Liberties Press.

---. 2012. "Of Migrants and Memory". Address by President Michael D. Higgins at Queen's University, Belfast on Tuesday, 30th October 2012.18 June 2013. http:// www.president.ie/speeches/remarks-by-president-michael-d-higgins-at-queensuniversity-belfast-on-tuesday-30th-october-2012-of-migrants-and-memory/

Howe, S. 2000. Ireland and Empire: Colonial Legacies in Irish History and Culture. Oxford: Oxford University Press.

Longley, E. 1994. The Living Stream: Literature and Revisionism in Ireland. Newcastle upon Tyne: Bloodaxe.

Lloyd. D. 1993. Anomalous States: Irish Writing and the Post-Colonial Moment. Dublin: Lilliput.

---. 1999. Ireland after History. Critical Conditions: Field Day Essays and Monographs. Cork: Cork University Press.

McDonald, K. 2013. "Belfast: 'It's not just the flag. They want to take everything British away"". The Guardian 12 Jan. 18 June 2013. http://www.guardian.co.uk/ uk/2013/jan/13/belfast-protest-flag-young-loyalists 
McGrath, F.C. 2012. "Settler Nationalism: Ulster Unionism and Postcolonial Theory". Irish Studies Review 20, 4: 463-485.

McLeod, J. 2000. Beginning Postcolonialism. Manchester: Manchester University Press.

Richards, S. 1999. "Foreword". Ireland in Proximity: History, Gender, Space. Eds. S. Brewster, V. Crossman, F. Becket and D. Alderson. London: Routledge. xi-xv.

SAID, E. W. 1986. "Intellectuals in the Post-Colonial World". Salmagundi springsummer: 44-64.

---. 1994. Representations of the Intellectual. The Reith Lectures. London: Vintage.

---. 1995. Orientalism: Western Conceptions of the Orient. 1978. New Afterword. London: Penguin.

---. 2003. "Afterword: Reflections on Ireland and Postcolonialism". Ireland and Postcolonial Theory. Eds. C. CARroll and P. King. Cork: Cork University Press. 177-185. 